Volume 15 Nomor 2, Desember 2019

\title{
Determinan Jumlah Uang Beredar, Tingkat Bunga, dan Inflasi terhadap Pertumbuhan Ekonomi Indonesia
}

\author{
Adya Utami \\ STIE Tri Dharma Nusantara \\ adya.utami@gmail.com
}

\begin{abstract}
This study aims to determine the determinants of the money supply, the interest rate, and inflation on Indonesia's economic growth in the 2009-2018 period. This research uses descriptive method and is strengthened by the OLS (ordinary least square) method with secondary data. The data used is sourced from the Central Statistics Agency and Bank Indonesia. The results of this study indicate that the money supply and the interest rate have a negative effect but inflation has a positive effect on Indonesia's economic growth. The JUB variable is not significant with a probability value of 0.1326 . The JUB regression coefficient value has a negative relationship to the economic growth variable with $a$ coefficient of 0.9288 . The interest rate variable entered in the above equation turns out to be negative and significant with a probability value of 0.0571. The value of the coefficient of the exchange rate is (0.4843). The independent variable inflation gives a negative and not significant result with a probability value of 0.1134. Inflation coefficient value is 0.1724 . In the equation model that uses economic growth as the dependent variable above, the magnitude of the coefficient of determination ( $R$ Squared) is 0.573429. This shows that the ability of the independent variable in explaining the diversity of the independent variables is $57.34 \%$ while the remaining $42.66 \%$ is influenced by other variables not included in the model.
\end{abstract}

Keywords: Amount of Money Supply; Interest Rates; Inflation; Economic growth

\section{A. PENDAHULUAN}

Perkembangan ekonomi suatu Negara tentu mengalami pasang surut (siklus) yang pada periode tertentu perekonomian tumbuh pesat dan pada periode lain tumbuh melambat. Untuk memengaruhi perkembangan perekonomian agar dapat berlangsung dengan baik dan stabil, pemerintah atau otoritas moneter biasanya melakukan langkah kebijakan untuk mengelola sisi permintaan dan sisi penawaran suatu perekonomian agar mengarah pada kondisi keseimbangan dengan tingkat pertumbuhan ekonomi yang berkelanjutan.

Bank Indonesia memegang peranan sebagai otoritas moneter di Indonesia. Di dalam kebijakan moneter, efektivitas kebijakan moneter tergantung pada hubungan antara jumlah uang beredar dengan variabel ekonomi utama seperti output (pertumbuhan ekonomi), tingkat bunga, dan inflasi. Dari sejumlah literatur, dapat dilihat berbagai temuan empiris yang menarik 
Volume 15 Nomor 2, Desember 2019

Halaman 45-64
Determinan Jumlah uang Beredar, Tingkat Bunga, dan inflasi terhadap Pertumbuhan Ekonomi indonesia

mengenai hubungan antara uang beredar, inflasi, tingkat bunga, dan output. Temuan empiris tersebut secara umum menyimpulkan bahwa dalam jangka panjang, hubungan antara pertumbuhan yang berdar dan inflasi adalah sempurna, sementara hubungan antara pertumbuhan uang atau inflasi dengan pertumbuhan output riil mungkin mendekati nol. Sementara tingkat bunga merupakan kebijakan otoritas moneter dengan melihat kondisi ekonomi global.

Beberapa studi mengenai pengaruh kebijakan moneter pada kegiatan ekonomi untuk kasus Indonesia telah dilakukan terutama dengan mengaitkannya dengan isu mekanisme transmisi kebijakan moneter (Warjiyo dan Agung, 2002; Muelgeni, 2004). Dalam kerangka pemikiran berbeda, Solikin (2005) melakukan studi mengenai pengaruh policy variabels dari kebijakan moneter pada sasaran akhir kebijakan, yaitu output, inflasi, dan kesempatan kerja. Studi tersebut dilakukan melalui pengembangan model structural cointegration vector autoregression (SVAR). Keterkaitan antar-variabel dan panjang lag kebijakan moneter diamati melalui analisis fungsi impuls respons dengan identifikasi keterkaitan inovasi fungsional yang mengacu pada kondisi umum. Terdapat Sembilan variabel yang berperan dalam system ekonomi, yaitu suku bunga kebijakan (Sertifikat Bank Indonesia, SBI) dan uang primer, yang keduanya merupakan policy variabels, output (PDB), inflasi (IHK), kesempatan kerja, nilai tukar, suku bunga luar negeri (LIBOR), dan indeks harga saham (JSX).

Kenaikan Federal Funds Rate (FFR) di AS dan ketidakpastian pasar keuangan global telah menurunkan aliran masuk modal asing ke negara berkembang, termasuk Indonesia. Kondisi ini memberikan tantangan bagi kebijakan moneter di negara dengan perekonomian terbuka.

Defisit transaksi berjalan yang melebar sejalan permintaan domestik yang tetap solid, aliran masuk modal asing yang berkurang pada gilirannya menurunkan kinerja neraca pembayaran Indonesia (NPI) dan meningkatkan tekanan kepada nilai tukar Rupiah. Tantangan ini terutama terlihat pada triwulan II dan III 2018, sehingga perlu direspons dengan segera karena berisiko mengganggu stabilitas perekonomian dan sistem keuangan serta momentum pemulihan ekonomi.

Permintaan domestik yang tumbuh tinggi pada gilirannya mendorong peningkatan impor pada 2018. Impor pada 2018 bertumbuh 12,04\%, lebih tinggi dibandingkan dengan kinerja 2017 sebesar $8,06 \%$. Peningkatan impor ini tidak terlepas dari peningkatan kebutuhan domestik untuk 
Volume 15 Nomor 2, Desember 2019

Halaman 45-64
Determinan Jumlah uang Beredar, Tingkat Bunga, dan inflasi terhadap Pertumbuhan Ekonomi indonesia

proyek infrastruktur yang diyakini dapat menopang produktivitas perekonomian pada masa mendatang.

Peningkatan impor terutama dipengaruhi kenaikan impor barang di semua kategori yakni bahan baku, barang modal, dan barang konsumsi. Impor bahan baku yang mencakup lebih dari 70\% impor nonmigas meningkat didorong kebutuhan yang tinggi untuk mendukung aktivitas produksi seperti besi baja, bahan kimia organik, pakan ternak, dan emas. Peningkatan impor bahan baku juga didorong kebutuhan suku cadang dan peralatan untuk barang modal terkait proyek kelistrikan dan telekomunikasi. Selanjutnya, kinerja investasi nonbangunan yang tumbuh tinggi juga mendorong peningkatan impor barang modal terutama impor nontransportasi terkait mesin dan perlengkapan baik di sektor industri maupun konstruksi. Begitu pula impor konsumsi yang meningkat sejalan dengan peningkatan kinerja konsumsi rumah tangga.

Pertumbuhan impor mulai melambat pada triwulan IV 2018. Impor pada triwulan IV 2018 tumbuh 7,10\%, melambat dari tiga triwulan sebelumnya yang rata-rata mencapai sekitar 14\%. Penurunan ini tidak terlepas dari dampak positif bauran kebijakan yang ditempuh Pemerintah dan Bank Indonesia, termasuk program pemerintah untuk mengendalikan impor serta dampak pergerakan nilai tukar Rupiah.

Di sisi lain, kinerja ekspor melambat akibat penurunan volume perdagangan dunia dan harga komoditas. Ekspor pada 2018 tumbuh 6,48\%, lebih rendah dari kinerja 2017 yang tumbuh $8,91 \%$. Pertumbuhan ekonomi global yang melambat serta berdampak pada perlambatan volume perdagangan dunia dan penurunan harga komoditas, pada gilirannya memberikan tekanan pada kinerja ekspor Indonesia. Berdasarkan negara tujuan ekspor, perlambatan ekspor dipengaruhi oleh penurunan permintaan dari mitra dagang utama seperti Tiongkok, Jepang, dan Korea Selatan, di tengah kinerja ekspor Indonesia ke Amerika Serikat (AS) yang menguat sejalan akselerasi ekonomi AS pada 2018.

Kinerja ekspor nasional yang tumbuh melambat terutama tergambar pada kontraksi ekspor Kalimantan dan Bali-Nusra serta kinerja ekspor Sumatera yang melambat. Kontraksi ekspor Kalimantan dipengaruhi terutama oleh penurunan ekspor CPO seiring dengan tren penurunan harga global dan penurunan ekspor batu bara akibat pelemahan permintaan dari Tiongkok. Di Bali-Nusra, kontraksi disebabkan oleh menurunnya ekspor konsentrat tembaga di 
Volume 15 Nomor 2, Desember 2019

Halaman 45-64
Determinan Jumlah uang Beredar, Tingkat Bunga, dan inflasi terhadap Pertumbuhan Ekonomi indonesia

Provinsi NTB seiring dengan pengembangan blok tambang baru yang mengakibatkan tidak tercapainya target produksi. Sementara itu, penurunan harga global CPO juga memengaruhi kinerja ekspor Sumatera. Namun demikian, perlambatan ekspor Sumatera yang lebih dalam tertahan oleh peningkatan ekspor batu bara dan produk kimia.

\section{B. METODE}

Metode yang digunakan dalam penelitian ini adalah metode analisis regresi sederhana. Untuk mengetahui hubungan antara tingkat bunga, inflasi, dan jumlah uang beredar terhadap pertumbuhan ekonomi di Indonesia periode 2009 - 2018.

Adapun persamaan fungsinya adalah sebagai berikut :

$$
Y=f(I N T, J U B, I N F)
$$

Dimana :

$\mathrm{Y}=$ Pertumbuhan ekonomi

INT $=$ Tingkat bunga

JUB = Jumlah uang beredar

$\mathrm{INF}=$ Inflasi

Sedangkan untuk mengetahui tingkat signifikansi dari masing-masing koefisien regresi variabel independen terhadap variabel dependen maka penulis menggunakan uji statistikdiantaranya :

1. Analisis koefisien determinasi $\left(\mathrm{R}^{2}\right)$. Analisis koefisien determinasi digunakan untuk mengukur seberapa besar pengaruh variabel independent (tingkat bunga,inflasi,PDB dan exchange rate) terhadap variabel dependen (Penanaman Modal Asing).

2. Uji Statistik F. Uji ini digunakan untuk mengetahui pengaruh variabel independent secara signifikan terhadap variabel dependen,dimana tingkat signifikansi yang digunakan yaitu 5 $\%$.

3. Uji Statistik t.Uji ini digunakan untuk mengetahui apakah masing-masing variabel independen secara sendiri-sendiri mempunyai pengaruh secara signifikan terhadap variabel dependen, dimana tingkat signifikan yang digunakan yaitu $5 \%$. 
Volume 15 Nomor 2, Desember 2019

Halaman 45-64
Determinan Jumlah uang Beredar, Tingkat Bunga, dan inflasi terhadap Pertumbuhan Ekonomi indonesia

\section{HASIL DAN PEMBAHASAN}

\section{Tingkat Bunga}

Suku Bunga di Indonesia merupakan suku bunga yang mencerminkan sikap dari kebijakan moneter yang ditetapkan oleh bank Indonesia.Tingkat suku bunga Bank digunakan untuk mengontrol perekonomian suatu negara, diatur dan ditetapkan pemerintah dengan tujuan menjaga kelangsungan perekonomian suatu negara.

Bank Indonesia melakukan penguatan kerangka operasi moneter dengan mengimplementasikan suku bunga acuan atau suku bunga kebijakan baru yaitu BI 7-Day (Reverse) Repo Rate, yang berlaku efektif sejak 19 Agustus 2016, menggantikan BI Rate. Penguatan kerangka operasi moneter ini merupakan hal yang lazim dilakukan di berbagai bank sentral dan merupakan best practice internasional dalam pelaksanaan operasi moneter. Kerangka operasi moneter senantiasa disempurnakan untuk memperkuat efektivitas kebijakan dalam mencapai sasaran inflasi yang ditetapkan. Instrumen BI 7-day (Reverse) Repo Rate digunakan sebagai suku bunga kebijakan baru karena dapat secara cepat memengaruhi pasar uang, perbankan dan sektor riil. Instrumen BI 7-Day Repo Rate sebagai acuan yang baru memiliki hubungan yang lebih kuat ke suku bunga pasar uang, sifatnya transaksional atau diperdagangkan di pasar, dan mendorong pendalaman pasar keuangan, khususnya penggunaan instrumen repo.

Penggunaan instrumen BI 7-day (Reverse) Repo Rate sebagai suku bunga kebijakan baru, diharapkan memberikan dampak: 1) menguatnya sinyal kebijakan moneter dengan suku bunga (Reverse) Repo Rate 7 hari sebagai acuan utama di pasar keuangan; 2) meningkatnya efektivitas transmisi kebijakan moneter melalui pengaruhnya pada pergerakan suku bunga pasar uang dan suku bunga perbankan; 3) terbentuknya pasar keuangan yang lebih dalam, khususnya transaksi dan pembentukan struktur suku bunga di pasar uang antarbank (PUAB) untuk tenor 3-12 bulan.

Tingkat Suku bunga Indonesia selama periode 2014 sampai dengan tahun 2018 dapat dilihat pada grafik berikut: 
Volume 15 Nomor 2, Desember 2019

Halaman 45-64
Determinan Jumlah uang Beredar, Tingkat Bunga, dan inflasi terhadap Pertumbuhan Ekonomi indonesía

Gambar 1. Suku Bunga Indonesia periode 2014 - 2018

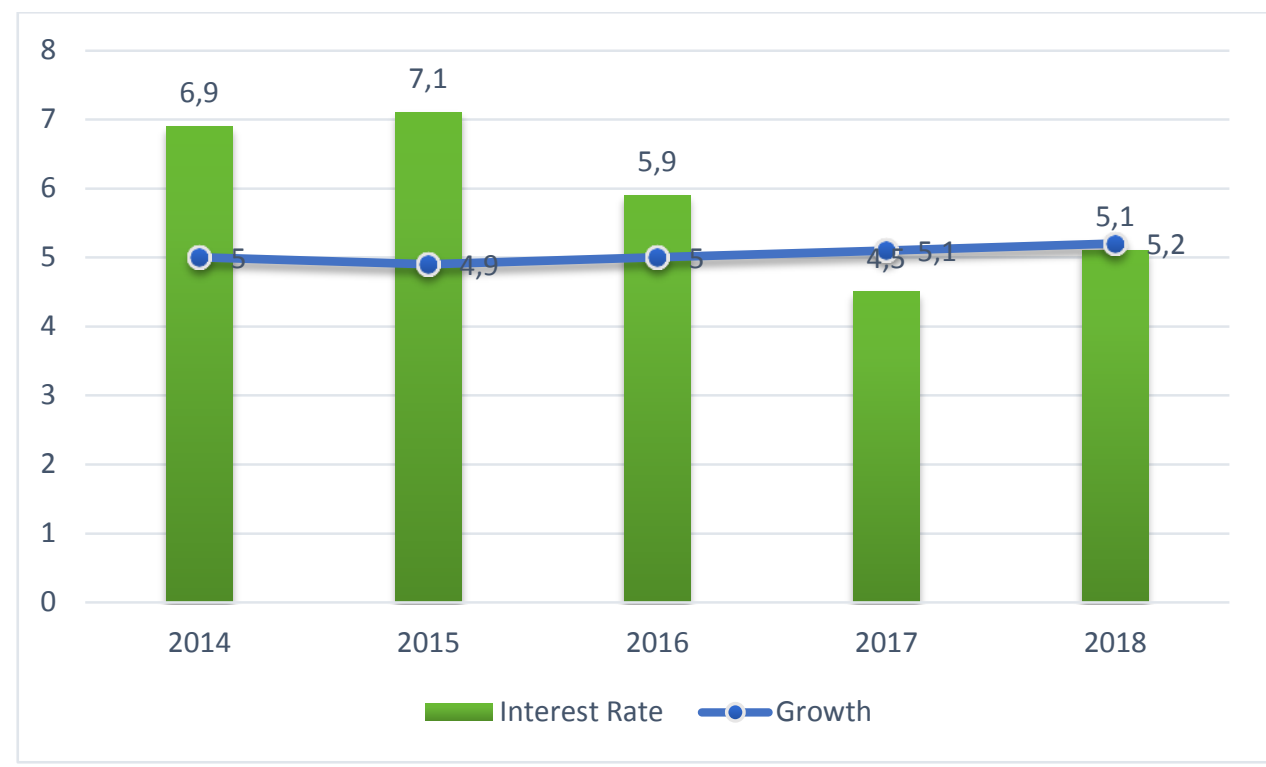

Sumber: Data Diolah, 2019

Dari grafik terlihat bahwa pertumbuhan ekonomi Indonesia melemah dari tahu 20142019 hanya berada pada kisaran $5 \%$. Angka ini jauh lebih rendah dibandingkan dengan periode tahun 2012 sebesar 6,23\%. Pertumbuhan ekonomi melemah karena kinerja ekspor sampai akhir 2019mengalami penurunan walaupun tingkat suku bunga turun pada tahun 2017. Hal ini disebabkan karena anjloknya harga beberapa komoditas andalan Indonesia seperti batubara dan crude palm oil (CPO). Di sisi lain, tekanan global masih jadi momok bagi kinerja ekspor. Pelemahan ekonomi global akibat perang dagang Amerika Serikat (AS) dan China membuat permintaan global menurun.

Kenaikan suku bunga sebesar 50 basis poin dari 4,25\% menjadi 4,75\%terjadi pada bulan Mei 2018 menyebabkan aliran modal masuk banyak ke Indonesia. Ini merupakan imbas dari kenaikan suku bunga acuan Amerika Serikat (AS) Fed Rate yang naik 75 basis poin dalam setahun terakhir. Kenaikan suku bunga acuan memiliki hubungan negatif dengan pertumbuhan ekonomi, karena suku bunga yang tinggi menjadi disinsetif bagi penyaluran kredit yang berdampak pada investasi riil dan menjadi pemicu bagi masyarakat untuk menaruh uangnya di instrumen keuangan. Selain itu suku bunga acuan juga akan mempengaruhi suku bunga pinjaman, sehingga masyarakat tidak termotivasi melakukan konsumsi. Dengan imbal hasil yang 
Volume 15 Nomor 2, Desember 2019

Halaman 45-64
Determinan Jumlah uang Beredar, Tingkat Bunga, dan inflasi terhadap Pertumbuhan Ekonomi indonesia

lebih besar, masyarakat akanmengurangi konsumsi dan cenderung memilih menahan uangnya di bank.Hal ini mempengaruhi pertumbuhan ekonomi karena investasi dan konsumsi merupakan bagian dari pembentuk Produk Domestik Bruto (PDB), selain ekspor netto dan pengeluaran pemerintah.

Saat suku bunga acuan BI Rate di angka 7,1\%, pertumbuhan ekonomi Indonesia mencapai 4,9\%. Hal ini disebabkan karena pertumbuhan ekonomi Indonesia sangat dipengaruhi harga komoditas.Berdasarkan data BPS, sektor pertanian dan pertambangan mengambil porsi terbesar dalam pembentuk PDB Indonesia di kuartal I, yakni 21,29 \%.Kenaikan harga komoditas juga punya efek menyebar terhadap lapangan usaha lain, seperti perdagangan serta transportasi dan pergudangan. Sehingga, kala harga komoditas naik, maka nilai output perekonomian meningkat, dan ini bisa memperbaiki investasi, konsumsi masyarakat, dan ekspor.

Penurunan suku bunga acuan atau BI 7-day Reverse Repo Rate (BI7DRR) sebanyak dua kali terjadi sepanjang tahun 2019. Bank Indonesia menurunkan suku bunga acuan untuk pertama kalinya pada bulan Juli 2019 yakni turun 25 bps dari $6 \%$ menjadi 5,75\%. Pada bulan Agustus 2019 Bank Indonesia kembali memutuskan untuk menurunkan BI 7-day Reverse Repo Rate (BI7DRR) sebesar 25 basis poin menjadi 5,50\%. Bulan September 2019 kembali diturunkan 25 basis poin menjadi 5.25\%. Selain itu, suku bunga Deposit Facility juga turun sebesar 25 basis poin menjadi sebesar 4,75 \%, dan suku bunga Lending Facility turun 25 basis poin menjadi $5,25 \%$.

Bank Indonesia (BI) memutuskan untuk menurunkan suku bunga acuannya dengan alasan:

a. Rendahnya perkiraan inflasi hingga 2020. "Rendahnya prakiraan inflasi yang berada di bawah titik tengah sasaran $3,5 \%$ plus minus $1 \%$ akan tetap berada dalam sasaran $3 \%$ pada 2020

b. Imbal hasil investasi masih akan menarik meski suku bunga acuan BI turun. Tetap menariknya imbal hasil keuangan domestik, bisa diukur perbedaan suku bunga baik dalam riil policy rate $2,5 \%$ diferensialnya kemudian nominal interest rate diferensial kalau terkait cover $4,16 \%$ kalo uncover tanpa premi risiko 5,74\%. 
Volume 15 Nomor 2, Desember 2019

Halaman 45-64
Determinan Jumlah uang Beredar, Tingkat Bunga, dan inflasi terhadap Pertumbuhan Ekonomi indonesia

c. Meningkatkan penyaluran kredit oleh pihak perbankan yang diharapkan bisa mendorong percepatan perekonomian nasional sebagai langkah pre emptive untuk dorong momentum perekonomian dari dampak perlambatan ekonomi ke depan.

Kebijakan penurunan suku bunga ini menggunakan baseline skenario yang memperhitungkan dampak ketegangan perang dagang yang sudah terjadi terkait pengenaan tarif 10\% terhadap US\$250 miliar komoditas asal China oleh AS.

Bila dilihat dampaknya pada pertumbuhan ekonomi maka dapat dikatakan bahwa tingkat bunga berpengaruh terhadap pertumbuhan ekonomi, ini memberikan bukti bahwa tingkat suku bunga merupakan fungsi dari investasi. Tingkat suku bunga yang rendah dapat membuat investasi meningkat dan pada akhirnya akan berpengaruh pada pertumbuhan ekonomi yang akan meningkat. Hasil ini sesuai teori dimana teori menyatakan apabila suku bunga tinggi, maka jumlah investasi akan berkurang yang artinya pertumbuhan ekonomi akan turun, sebaliknya apabila suku bunga rendah maka akan mendorong banyak investasi yang sehingga dapat meningkatkan pertumbuhan ekonomi (Sukirno: 2010). Hal ini memberikan bukti bahwa suku bunga memiliki pengaruh terhadap pertumbuhan ekonomi baik itu secara positif maupun negatif.

Secara umum, kinerja tersebut menunjukkan perekonomian Indonesia tetap solid, mengingat pada saat bersamaan pertumbuhan ekonomi dunia 2018 dalam tren melambat dan ketidakpastian global sedang meningkat. Pertumbuhan Ekonomi dunia terlihat pada tabel 1.

Tabel 1 menunjukkan pertumbuhan ekonomi dunia secara agregat cenderung melambat namun US menunjukkan trend meningkat. Jepang mengalami penurunan yang tajam di tahun 2018 sekitar 50\% dari pertumbuhan ekonomi di tahun sebelumnya. India juga mengalami peningkatan pertumbuhan ekonomi yang lambat seperti halnya US.Perlambatan ekonomi tersebut dipicu oleh perlambatan konsumsi, investasi, dan kinerja ekspor, sebagai dampak dari penurunan daya beli, penurunan sentimen konsumen dan bisnis, serta pelemahan ekonomi global dan ketegangan perdagangan AS dengan Tiongkok. 
Volume 15 Nomor 2, Desember 2019

Halaman 45-64
Determinan Jumlah uang Beredar, Tingkat Bunga, dan inflasi terhadap Pertumbuhan Ekonomi indonesía

\section{Tabel 1. Pertumbuhan Ekonomi Dunia Tahun 2014-2018}

\begin{tabular}{|c|c|c|c|c|c|}
\hline $\begin{array}{c}\text { Negara/Kelompolk } \\
\text { Negara }\end{array}$ & 2014 & 2015 & 2016 & 2017 & $2018 *$ \\
\hline Dunia & 3.4 & 3.5 & 3.3 & 3.8 & 3.7 \\
\hline Negara Maju & 1.8 & 2.3 & 1.7 & 2.4 & 2.3 \\
\hline US & 2.4 & 2.9 & 1.6 & 2.2 & 2.9 \\
\hline Iepang & -0.03 & 1.3 & 0.6 & 1.9 & 0.8 \\
\hline Eropa & 0.9 & 2.1 & 2 & 2.4 & 1.8 \\
\hline Ingaris & 2.9 & 2.3 & 1.8 & 1.8 & 1.4 \\
\hline Negara Berkembang & 4.6 & 4.3 & 4.4 & 4.7 & 4.6 \\
\hline Tiongkok & 7.3 & 6.9 & 6.7 & 6.8 & 6.6 \\
\hline India & 7.3 & 7.6 & 8 & 6.3 & 7.4 \\
\hline
\end{tabular}

Sumber: Laporan Perekonomian Indonesia, berbagai seri

Lesunya laju pertumbuhan ekonomi telah membuat beberapa bank sentral di seluruh dunia mengambil arah kebijakan moneter yang lebih lunak atau dovish. Beberapa bank sentral menurunkan suku bunga acuannya ke level terendah, seperti terlihat pada gambar 2 berikut:

\section{Gambar 2. Suku Bunga Kebijakan Moneter Negara Maju dan Berkembang}

\section{Suku Bunga Kebijakan Moneter Negara Maju}

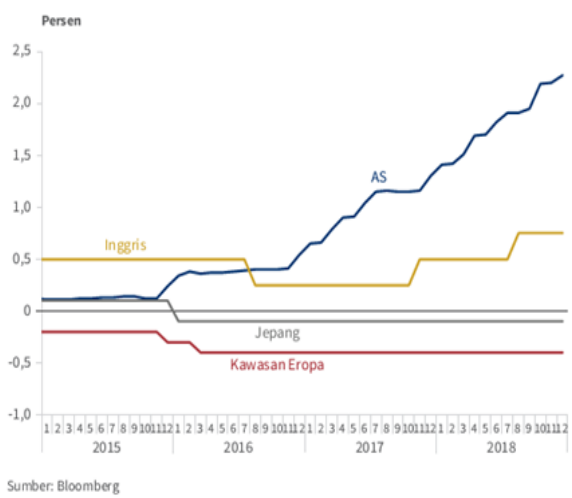

Suku Bunga Kebijakan Moneter Negara Berkembang

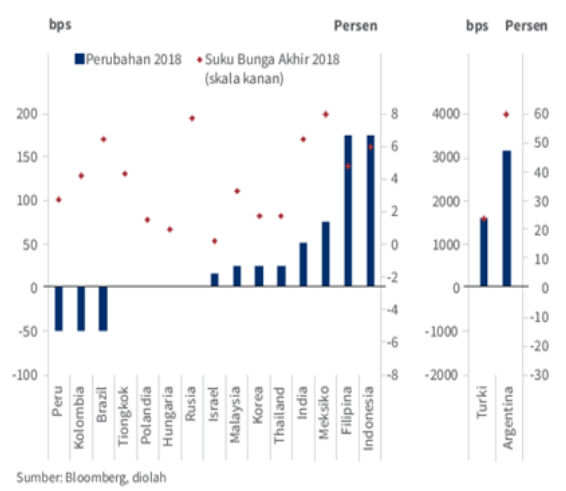

Sumber: Laporan Perekonomian Indonesia, 2018

Perlambatan ekonomi dan isu pemotongan suku bunga oleh The Fed menjadi pemicu perdebatan antara pemerintah dan bank sentral di beberapa negara. Sebagai antisipasi adanya kemungkinan pemotongan suku bunga oleh The Fed, beberapa negara akhirnya mulai menurunkan suku bunga kebijakannya pada triwulan ini. Malaysia dan Filipina memotong suku 
Volume 15 Nomor 2, Desember 2019

Halaman 45-64
Determinan Jumlah uang Beredar, Tingkat Bunga, dan inflasi terhadap Pertumbuhan Ekonomi indonesia

bunga pada bulan Mei sebanyak 25 bps. Selain itu, Australia dan India memangkas suku bunga sebesar 25 bps pada bulan Juni. Bank Indonesia sendiri telah mendapat desakan dari berbagai pihak untuk segera menurunkan suku bunga acuan.

Negara maju rata-rata memilih untuk menahan suku bunga kebijakannya. The Fed menahan suku bunga sebesar 2,25-2,5 \% sepanjang triwulan II tahun 2019. Hal tersebut dilakukan dengan pertimbangan inflasi dan pengangguran yang cukup rendah. The Fed akan terus menyesuaikan dengan kondisi ekonomi domestikmaupun perkembangan kebijakan perdagangan Amerika Serikat.The People Bank of China (PboC) juga memutuskan untuk mempertahankan suku bunga kebijakannya sepanjang triwulan ini pada level 2,25\%. Keputusan tersebut diambil sebagai upaya untuk menjaga perekonomian domestik. PBoC menilai pemotongan suku bunga merupakan langkah terakhir untuk mendorong aktivitas perekonomiannya.

\section{Inflasi}

Inflasi adalah kenaikan harga secara umum dan terus menerus dalam jangka waktu tertentu. Kenaikan harga dari satu atau dua barang saja tidak dapat disebut inflasi kecuali bila kenaikan itu meluas atau mengakibatkan kenaikan harga pada barang lainnya. Kebalikan dari inflasi disebut deflasi.

Indikator yang sering digunakan untuk mengukur tingkat inflasi adalah Indeks Harga Konsumen (IHK). Perubahan IHK dari waktu ke waktu menunjukkan pergerakan harga dari paket barang dan jasa yang dikonsumsi masyarakat. Penentuan barang dan jasa dalam keranjang IHK dilakukan atas dasar Survei Biaya Hidup (SBH) yang dilaksanakan oleh Badan Pusat Statistik (BPS). Kemudian, BPS akan memonitor perkembangan harga dari barang dan jasa tersebut secara bulanan di beberapa kota, di pasar tradisional dan modern terhadap beberapa jenis barang/jasa di setiap kota.

Inflasi timbul karena adanya tekanan dari sisi supply (cost push inflation), dari sisi permintaan (demand pull inflation), dan dari ekspektasi inflasi. Faktor-faktor terjadinya cost push inflation dapat disebabkan oleh depresiasi nilai tukar, dampak inflasi luar negeri terutama negara-negara partner dagang, peningkatan harga-harga komoditi yang diatur pemerintah 
Volume 15 Nomor 2, Desember 2019

Halaman 45-64
Determinan Jumlah uang Beredar, Tingkat Bunga, dan inflasi terhadap Pertumbuhan Ekonomi indonesia

(administered price), dan terjadi negative supply shocks akibat bencana alam dan terganggunya distribusi.

Laju inflasi merupakan suatu indikator yang sangat menentukan perekonomian makro suatu negara. Inflasi juga merupakan suatu masalah bagi ekonomi makro yang apabila tidak segera ditanganin akan menyebabkan ketidakstabilan perekonomian yang pada akhirnya hanya bisa memperburuk kinerja suatu perekonomian negara. Ketidakstabilan mata uang baik inflasi atau nilai tukar, sangat penting dalam mendukung pembangunan ekonomi yang berkelanjutan dan meningkatkan kesejahteraan rakyat.

\section{a. Inflasi dan Pertumbuhan Ekonomi Indonesia}

Target inflasi merupakan tingkat inflasi yang harus dicapai oleh Bank Indonesia, berkoordinasi dengan Pemerintah. Sejak tahun 2000Indonesia menggunakan Inflation Targeting Framework (ITF). ITF merupakan suatu kerangka kebijakan moneter yang mempunyai ciri-ciri utama, yaitu adanya pernyataan resmi dari bank sentral dan dikuatkan dengan undang-undang bahwa tujuan akhir kebijakan moneter adalah mencapai dan menjaga tingkat inflasi yang rendah, serta pengumuman target inflasi kepada publik. Pengumuman tersebut mengundang arti bahwa bank sentral memberikan komitmen dan jaminan kepada publik bahwa setiap kebijakan moneternya selalu mengacu pada pencapaian target tersebut dan bank sentral mempertanggungjawabkan kebijakannya apabila target tersebut tidak tercapai.

Prinsip dasar yang melandasi kerangka kerja Inflation Targetting tersebut adalah bahwa sasaran akhir dari kebijakan moneter diutamakan untuk mencapai dan memelihara laju inflasi yang rendah dan stabil. Hal ini didasarkan pada dua pertimbangkan pokok, yaitu:1) Laju inflasi yang tinggi menimbulkan biaya sosial yang harus ditanggung oleh masyarakat karena menurunnya daya beli atas pendapatan yang diperolehnya maupun meningkatnya ketidakpastian yang dapat mempersulit perencanaan usaha dan memperburuk kegiatan perekonomian. 2) Perkembangan teori ekonomi dalam literatur dan temuan empiris di berbagai negara menunjukkan bahwa kebijakan moneter dalam jangka menengah-panjang hanya berpengaruh pada inflasi dan bukan pada pertumbuhan ekonomi dalam jangka pendek.

Berdasarkan dua pertimbangkan tersebut, maka kontribusi optimal yang dapat disumbangkan oleh kebijakan moneter dalam meningkatkan kesejahteraan sosial masyarakat 
Volume 15 Nomor 2, Desember 2019

Halaman 45-64
Determinan Jumlah uang Beredar, Tingkat Bunga, dan inflasi terhadap Pertumbuhan Ekonomi indonesia

adalah dengan pencapaian dan pemeliharaan laju inflasi yang rendah dan stabil. Dalam kaitan ini, pengendalian inflasi ini melalui kebijakan moneter tersebut adalah dalam rangka stabilitas dan penurunan laju inflasi dalam jangka menengah-panjang.

Penetapan sasaran inflasi berdasarkan UU mengenai Bank Indonesia dilakukan oleh Pemerintah. Dalam Nota Kesepahaman antara Pemerintah dan Bank Indonesia, sasaran inflasi ditetapkan untuk tiga tahun ke depan melalui Peraturan Menteri Keuangan (PMK). Berdasarkan PMK No.93/PMK.011/2014 tentang Sasaran Inflasi tahun 2016, 2017, dan 2018 tanggal 21 Mei 2014 sasaran inflasi yang ditetapkan oleh Pemerintah untuk periode 2016 - 2018, masing-masing sebesar 4\%, 4\%, dan 3,5\%, dengan deviasi masing-masing $\pm 1 \%$. Sementara, sasaran inflasi 2019-2021 ditetapkan berdasarkan Peraturan Menteri Keuangan No. 124/PMK.010/2017, masing-masing sebesar 3,5\%,3,0\% dan 3,0\%, dengan deviasi masing-masing $\pm 1 \%$.

Sasaran inflasi tersebut diharapkan dapat menjadi acuan bagi pelaku usaha dan masyarakat dalam melakukan kegiatan ekonominya ke depan sehingga tingkat inflasi dapat diturunkan pada tingkat yang rendah dan stabil. Bank Indonesia dan Pemerintah senantiasa berkomitmen untuk mencapai sasaran inflasi yang ditetapkan tersebut melalui koordinasi kebijakan yang konsisten dengan sasaran inflasi tersebut. Salah satu upaya pengendalian inflasi menuju inflasi yang rendah dan stabil adalah dengan membentuk dan mengarahkan ekspektasi inflasi masyarakat agar mengacu pada sasaran inflasi yang telah ditetapkan.

Perkembangan laju inflasi di Indonesia dari tahun 2009-2018 dapat dilihat pada tabel 2 dan grafikberikut:

Tabel 2. Inflasi dan Pertumbuhan Ekonomi 2014-2018

\begin{tabular}{ccc}
\hline Tahun & Inflasi & PertumbuhanEkonomi (\%) \\
\hline 2014 & 8,36 & 5,0 \\
2015 & 3,35 & 4.9 \\
2016 & 3,02 & 5.0 \\
2017 & 3,61 & 5.1 \\
2018 & 3,13 & 5.17 \\
\hline
\end{tabular}

Sumber: BPS, 2019 
Volume 15 Nomor 2, Desember 2019

Halaman 45-64
Determinan Jumlah uang Beredar, Tingkat Bunga, dan inflasi terhadap Pertumbuhan Ekonomi indonesia

Data tabel 2 menunjukkan rata-rata inflasi tahunan umum Indonesia selama 5 tahun adalah 5,04\% per tahun. Inflasi 2018 terkendali sesuai dengan sasaran inflasi 3,5 $\pm 1 \%$ dan mendukung pertumbuhan ekonomi tetap kuat. Perkembangan positif tersebut tidak terlepas dari transmisi kebijakan moneter yang berjalan baik dan stabilitas sistem keuangan yang terkendali. Grafik inflasi dan pertumbuhan ekonomi Indonesia terlihat pada Gambar 3.

Grafik pada gambar 3 menunjukkan bahwa kinerja pertumbuhan ekonomi 2018 mencapai $5,17 \%$. Realisasi tersebut merupakan yang tertinggi dalam lima tahun terakhir. Walaupun realisasi pertumbuhan Produk Domestik Bruto (PDB) tersebut tidak pernah melampaui target dalam APBN. Namun kinerja perekonomian Indonesia selama 2018 dinilai sebagai prestasi karena berada di tengah situasi perlambatan ekonomi global.

\section{Gambar 3. Inflasi dan Pertumbuhan Ekonomi}

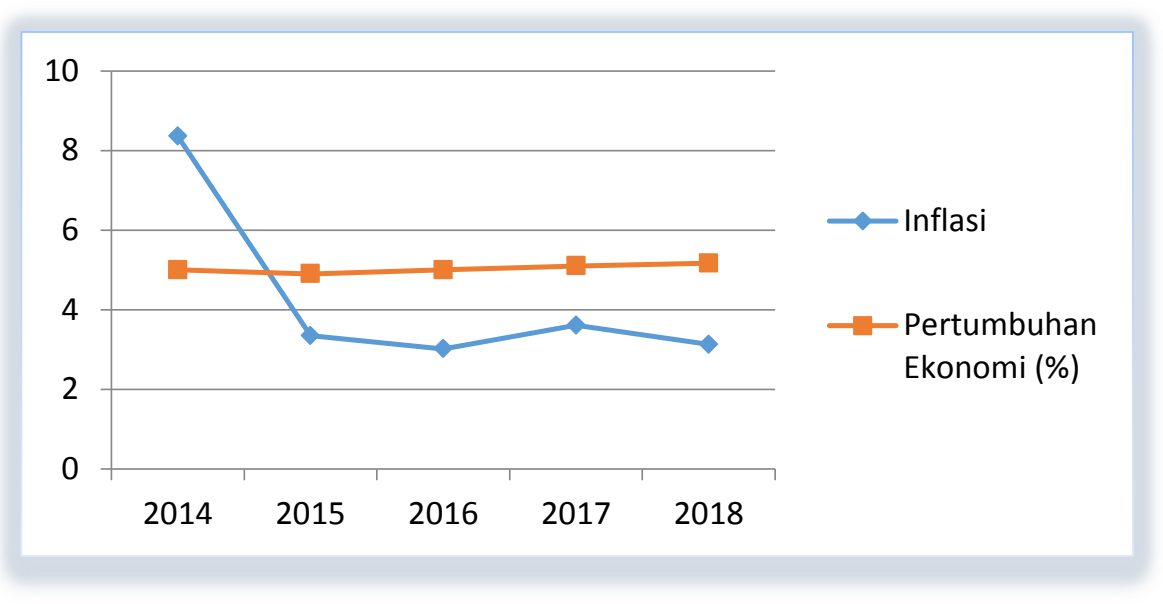

Sumber: Data Diolah, 2019

Situasi ini menyebabkan kinerja ekspor Indonesia tertekan. Kontribusi ekspor terhadap PDB cukup tinggi yakni sebesar $20 \%$. Pertumbuhan ekonomi 2018 didorong oleh meningkatnya pertumbuhan konsumsi rumah tangga, konsumsi pemerintah dan investasi, serta melonjaknya konsumsi lembaga non-profit yang melayani masyarakat menjelang Pemilihan Umum Presiden (Pilpres). Pemerintah telah berhasil menjaga inflasi rendah untuk pertumbuhan ekonomi. Hal ini berdampak kepada pertumbuhan konsumsi rumah tangga 5,05\% atau naik dari 4,98 \% pada 2017. 
Volume 15 Nomor 2, Desember 2019

Halaman 45-64
Determinan Jumlah uang Beredar, Tingkat Bunga, dan inflasi terhadap Pertumbuhan Ekonomi indonesia

Inflasi tahunan (YoY) pada April-Juni 2019 mencapai 2,83\%, 3,32 \%, dan 3,28\%, masih berada dalam rentang target yang ditetapkan sebesar 3,5 $\pm 1 \%$. Inflasi pada bulan Agustus tahun 2019 pada kelompok pendidikan, rekreasi, dan olahraga dengan inflasi sebesar 1,21 \%dengan andil 0,09\%.Pemerintah akan berupaya untuk menjaga inflasi sesuai target yaitu pada tingkat $3,1 \%$ untuk mendukung daya beli masyarakatserta pengelolaan keuangan dengan baik, maka inflasi akan teratasi lebih cepat dan tepat, karena inflasi yang rendah dan stabil merupakan prasyarat bagi pertumbuhan ekonomi yang berkesinambungan yang pada akhirnya memberikan manfaat bagi peningkatan kesejahteraan masyarakat. Pentingnya pengendalian inflasi didasarkan pada pertimbangan bahwa inflasi yang tinggi dan tidak stabil memberikan dampak negatif kepada kondisi sosial ekonomi masyarakat.

\section{b. Perkembangan Inflasi di Dunia}

Inflasi di dunia secara agregat menunjukkan tren meningkat seperti halnya untuk Kawasan Eropa. Kebijakan stimulus fiskal di tengah perbaikan ekonomi AS yang bersifat prosiklikal meningkatkan risiko kenaikan inflasi. Namun seiring pelemahan harga energi, indeks harga konsumen (inflasi) pada September 2018 menurun menjadi 2,3\% yoy, setelah berada pada level 2,9\% pada Juni. 2018. Sementara tekanan inflasi PCE core - yang menjadi acuan- telah berada di kisaran target 2\% sejak Mei 2018.

Gambar 4. Perkembangan Inflasi di Dunia

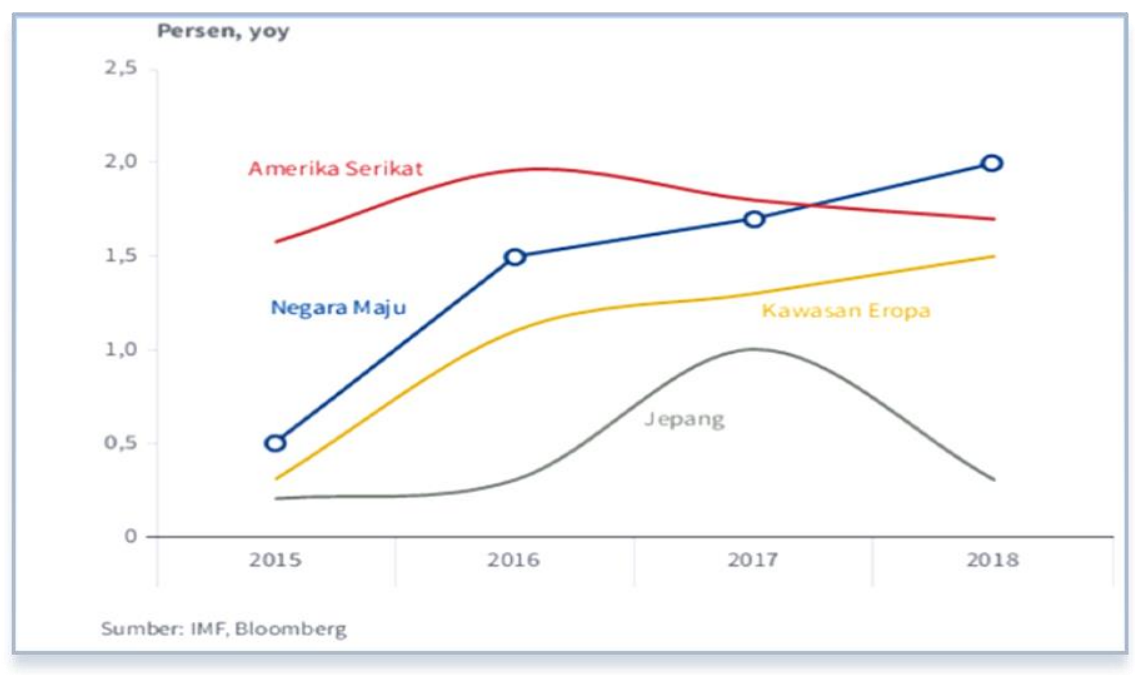

Sumber: Data Diolah, 2019 
Volume 15 Nomor 2, Desember 2019

Halaman 45-64
Determinan Jumlah uang Beredar, Tingkat Bunga, dan inflasi terhadap Pertumbuhan Ekonomi indonesia

Perbaikan kinerja ekonomi dan inflasi PCE core yang berada di kisaran target melatarbelakangi keputusan the Fed untuk melanjutkan normalisasi kebijakan moneter secara bertahap. The Fed telah menaikkan suku bunga Fed Fund Rate (FFR) sebesar 200 bps dalam delapan kali kenaikan sejak Desember 2015. Pada FOMC September 2018, the Fed kembali menaikkan FFR sebesar 25 bps, dan diperkirakan masih berlanjut pada FOMC Desember 2018. Inflasi US di tahun 2018 berbanding terbalik dengan pertumbuhan ekonomi US di tahun yang sama.

Sebaliknya bagi Jepang, inflasi dan pertumbuhan ekonomi menunjukkan keadaan yang sama. Pertumbuhan ekonomi jepang mencapai 2,5\% secara tahunan pada periode JuliSeptember. Ini adalah kenaikan dalam tujuh kuartal berturut-turut. Tapi, angka inflasi masih jauh dari target Bank of Japan sebesar 2\%. Jepang akan lebih lama mempertahankan kebijakan moneter longgar ketimbang negara-negara lain.

\section{Jumlah Uang Beredar}

Jumlah uang beredar dalam arti luas atau disebut M2 terdiri atas uang giral dan uang kartal, ditambah dengan uang kuasi seperti tabungan dan simpanan berjangka.Jumlah uang beredar memiliki pengaruh positif dan signifikan terhadap pertumbuhan ekonomi di Indonesia. Semakin meningkat jumlah uang beredar maka dapat meningkatkan pertumbuhan ekonomi, dengan peningkatan jumlah uang beredar, maka masyarakat akan menempatkan sebagian dananya untuk konsumsi sehingga membuat produsen memproduksi barang lebih banyak kemudian permintaan akan faktor produksi meningkat. Hal ini akan berpengaruh pada pendapatan perkapita kemudian akan meningkatkan pertumbuhan ekonomi.

Jumlah uang beredar dan pertumbuhan ekonomi di Indonesia dari tahun 2014-2018 terlihat pada tabel 3 berikut: 
Volume 15 Nomor 2, Desember 2019

Halaman 45-64

Determinan Jumlah uang Beredar, Tingkat Bunga, dan inflasi terhadap Pertumbuhan Ekonomi indonesía

Tabel 3. Jumlah Uang Beredar dan Pertumbuhan Ekonomi Indonesia

\begin{tabular}{cccc}
\hline Tahun & $\begin{array}{c}\text { JUB (M2) } \\
\text { (Triliun rupiah) }\end{array}$ & $\begin{array}{c}\text { Kenaikan JUB (M2) } \\
\text { (Triliun rupiah) }\end{array}$ & $\begin{array}{c}\text { Pertumbuhan Ekonomi } \\
(\%)\end{array}$ \\
\hline 2014 & 4173.3 & 422.9 & 5.0 \\
2015 & 4548.8 & 375.5 & 4.9 \\
2016 & 5005.0 & 456.2 & 5.0 \\
2017 & 5419.2 & 414.2 & 5.1 \\
2018 & 5760.0 & 340.8 & 5.2 \\
\hline
\end{tabular}

Sumber:BPS, 2019

Tabel 3menunjukkan bahwa jumlah uang beredar di Indonesia meningkat setiap tahunnya.Kenaikan paling tinggi terjadi pada tahun 2016 sebesar 456.2 triliun dimana tahun 2015 jumlah uang beredar sebesar4548.8 triliundengan pertumbuhan ekonomi sebesar 4,9\% . Tahun 2017 jumlah uang beredar naik sebesar 414.2 triliun menjadi 5419.2triliundengan pertumbuhan ekonomi meningkat sebesar 5,1\%.\%. Tahun 2018 jumlah uang beredar sebesar 5760.0triliun.

Secara umum, likuiditas perekonomian atau uang beredar dalam arti luas (M2) tumbuh relatif stabil meski sempat mengalami perlambatan pada pertengah periode April -Juni 2018. Jika dibandingkan dengan akhir triwulan sebelumnya, posisi M2 pada akhir triwulan IItahun 2018 tumbuh 5,91\% (YoY) sebesarRp5.533,7 triliun, lebih rendah dibanding posisi akhir triwulan I tahun 2018 yang tumbuh sebesar 7,53\%tersebut bersumber dari seluruh komponennya (M1 dan uang kuasi) dan dipengaruhi oleh operasi keuangan pemerintah serta peningkatan aktiva luar negeri bersih di tengah perlambatan pertumbuhan aktiva dalam negeri.

M1 pada bulan Juni 2018 sebesar Rp 1.452,4 triliun atau tumbuh sebesar 8,24\%(YoY), lebih tinggi dibandingkan pertumbuhan bulan Maret 2018 sebesar 11,95\% (YoY). Penurunan pertumbuhan M1 dipengaruhi oleh penurunan uang kartal seiring dengan perlambatan konsumsi masyarakat pasca Hari Raya Idul Fitri pada pertengahan bulan.Likuiditas perekonomian atau uang beredar dalam arti luas (M2) tumbuh relatif stabil meski sempat mengalami perlambatan pada pertengah periode April -Juni 2018. Jika dibandingkan dengan akhir triwulan sebelumnya, posisi M2 pada akhir triwulan IItahun 2018 tumbuh 5,91\% (YoY) sebesarRp5.533,7 triliun, lebih rendah dibanding posisi akhir triwulan I tahun 2018 yang tumbuh sebesar 7,53\%. M1 pada bulan 
volume 15 Nomor 2, Desember 2019

Halaman 45-64
Determinan Jumlah uang Beredar, Tingkat Bunga, dan Inflasi terhadap Pertumbuhan Ekonomi indonesia

Juni 2018sebesar Rp 1.452,4 triliun atau tumbuh sebesar 8,24\% (YoY), lebih tinggi dibandingkan pertumbuhan bulan Maret 2018 sebesar 11,95\% (YoY). Penurunan pertumbuhan M1 dipengaruhi oleh penurunan uang kartal seiring dengan perlambatan konsumsi masyarakat pasca Hari Raya Idul Fitri pada pertengahan bulan.

\section{Gambar 5. Jumlah Uang Beredar Dan Pertumbuhan Ekonomi Tahun 2014-2018}

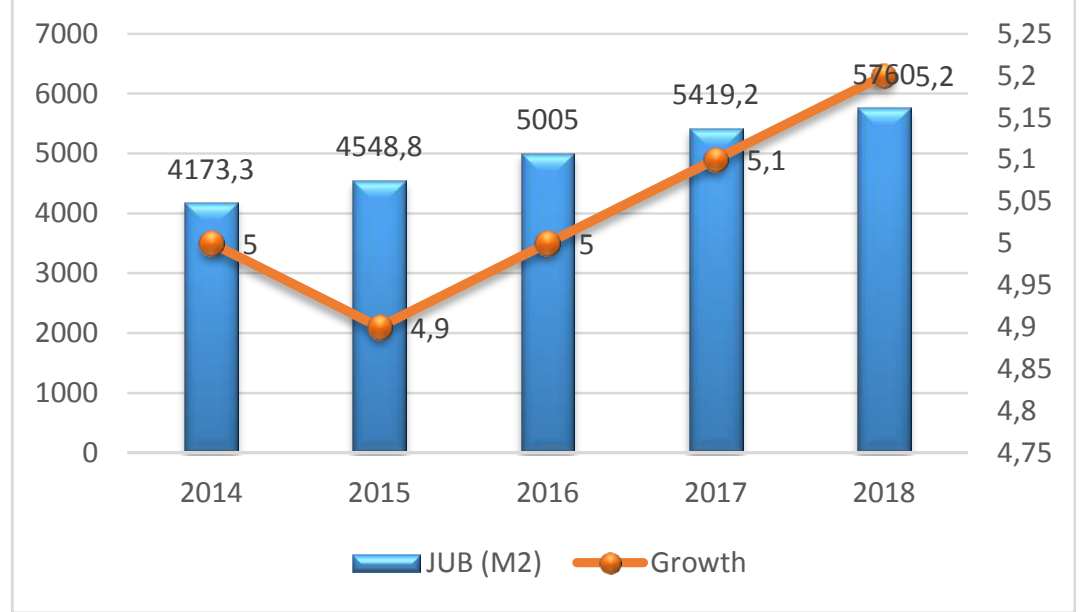

Sumber: Data Diolah, 2019

Jumlah peredaran uang tumbuh melambat secara tahunan pada Juni 2019 yang disebabkan oleh pertumbuhan ekonomiyang stagnan. Data Bank Indonesia (BI) menunjukkan jumlah uang beredar pada Juni 2019 tercatat sebesar Rp5.911,2 triliun atau tumbuh 6,8\% secara tahunan. Angka pertumbuhan ini melambat dibandingkan tahun lalu yang mencatat pertumbuhan $7,4 \%$.

Peredaran uang di masyarakat berkaitan dengan konsumsi masyarakat yang stagnan, sehingga tidak bisa mendorong pertumbuhan ekonomi. Terlebih, konsumsi menjadi kontributor utama pertumbuhan ekonomi, yakni 56,82\% dari PDB di kuartal I.

Pertumbuhan ekonomi dalam tiga hingga empat tahun terakhir yang berada di kisaran 5 $\%$ juga berimbas pada tren pertumbuhan uang beredar yang melandai. Pertumbuhan ekonomi bukan satu-satunya penyebab pertumbuhan uang beredar landai namun inflasi pun dapat menjadi 
Volume 15 Nomor 2, Desember 2019

Halaman 45-64
Determinan Jumlah uang Beredar, Tingkat Bunga, dan inflasi terhadap Pertumbuhan Ekonomi indonesia

penyebab pertumbuhan jumlah uang beredar karena masyarakat cenderung tidak ingin membelanjakan uangnya terlalu sering ketika harga barang dan jasa melonjak tinggi.

Pertumbuhan jumlah uang beredar yang melambat juga disebabkan oleh semakin meningkatnya penggunaan transaksi elektronik. Terlebih, uang elektronik tidak dimasukkan ke dalam formulasi uang beredar M1 atau M2. Untuk kegiatan sehari-hari, terjadi penurunan penggunaan uang kartal karena ada transaksi elektronik.

\section{Hasil Estimasi}

Dependent Variabel: Y

Method: Least Squares

Date: 10/14/19 Time: 21:00

Sample: 20092018

Included observations: 10

\begin{tabular}{lrlrr}
\hline \hline \multicolumn{1}{c}{ Variabel } & Coefficient & \multicolumn{1}{c}{ Std. Error } & t-Statistic & Prob. \\
\hline \multicolumn{1}{c}{ C } & 40.80932 & 19.43018 & 2.100306 & 0.0804 \\
JUB & -0.928809 & 0.533925 & -1.739588 & 0.1326 \\
INT & -0.484371 & 0.206156 & -2.349537 & 0.0571 \\
\multicolumn{1}{c}{ INF } & 0.172460 & 0.093105 & 1.852324 & 0.1134 \\
& 0.573429 & Mean dependent var & 5.437000 \\
R-squared & 0.360144 & S.D. dependent var & 0.655626 \\
Adjusted R-squared & 0.524442 & Akaike info criterion & 1.836210 \\
S.E. of regression & 1.650236 & Schwarz criterion & 1.957244 \\
Sum squared resid & -5.181050 & Hannan-Quinn criter. & 1.703436 \\
Log likelihood & 2.688555 & Durbin-Watson stat & 1.984722 \\
F-statistic & 0.139775 & & \\
Prob(F-statistic) & & & \\
\hline \hline
\end{tabular}

Berdasarkan hasil estimasi, dapat diketahui bahwa hubungan antara tingkat bunga, jumlah uang beredar, dan inflasi terhadap pertumbuhan ekonomi Indonesia periode 2009 - 2018 adalah:

$$
Y=40.80-0.928 J U B-0.484 I N T+0.172 I N F
$$

Persamaan di atas menunjukkan bahwa besarnya koefisien $\beta_{0}$ adalah 40,80 yang berarti bila variabel bebas (jumlah uang beredar, tingkat bunga, dan inflasi) konstan, maka pertumbuhan ekonomi Indonesia mengalami peningkatan sebesar 40,80 satuan. 
Volume 15 Nomor 2, Desember 2019

Halaman 45-64
Determinan Jumlah uang Beredar, Tingkat Bunga, dan inflasi terhadap Pertumbuhan Ekonomi indonesia

Pada model persamaan yang menggunakan pertumbuhan ekonomi sebagai variabel dependen di atas, besarnya nilai koefisien determinasinya ( $R$ Squared) adalah 0,573429. Hal ini menunjukkan bahwa kemampuan variabel independen (jumlah uang beredar, tingkat bunga, dan inflasi) dalam menerangkan keragaman variabel independen (pertumbuhan ekonomi) sebesar $57,34 \%$ sedangkan sisanya yaitu $42,66 \%$ dipengaruhi oleh variabel lainnya yang tidak termasuk dalam model.

\section{Penjelasan Uji Statistik}

\section{Uji F-Statistik}

Dari hasil perhitungan di atas memperlihatkan nilai $\mathrm{F}_{\text {hitung }} 2,68$ lebih besar daripada $\mathrm{F}_{\text {tabel }}$ 3,48 dengan $\mathrm{df}=10$ untuk penyebut dan $\mathrm{df}=4$ untuk pembilang $\left(\mathrm{F}_{\text {hitung }} 2,68<\mathrm{F}_{\text {tabel }} 3,48\right)$. Ini menunjukkan bahwa antara variabel independen dan variabel dependen mempunyai pengaruh tidak nyata. Sehingga factor- factor tersebut tidak cukup kuat untuk mendorong pertumbuhan ekonomi Indonesia.

\section{Uji t-Statistik}

Uji t-statistik digunakan untuk menguji tingkat signifikansi model secara parsial atau menguji keberartian pengaruh variabel independen (jumlah uang beredar, tingkat bunga, dan inflasi) terhadap variabel dependennya (pertumbuhan ekonomi).

a. Jumlah Uang Beredar (JUB). Pada model persamaan Y di atas, variabel JUB tidak signifikan dengan nilai probabilitas sebesar 0,1326. Nilai koefisien regresi JUB mempunyai hubungan negatif terhadap variabel pertumbuhan ekonomi dengan koefisien 0,9288 .

b. Tingkat Bunga. Variabel tingkat bunga yang dimasukkan dalam persamaan di atas ternyata menunjukkan negatif dan signifikan dengan nilai probabilitas sebesar 0,0571. Nilai koefisien kurs sebesar $(0,4843)$. 
Volume 15 Nomor 2, Desember 2019

Halaman 45-64
Determinan Jumlah uang Beredar, Tingkat Bunga, dan inflasi terhadap Pertumbuhan Ekonomi indonesia

c. Inflasi (INF). Variabel independen inflasi memberikan hasil negatif dan tidak signifikan dengan nilai probabilitas 0,1134. Nilai koefisien inflasi sebesar 0,1724.

\section{SIMPULAN}

Berdasarkan uraian latar belakang dan pembahasan makalah maka ditarik beberapa kesimpulan sebagai berikut:

1. Kondisi perekonomian global yang tidak pasti membuat Indonesia harus lebih berhati-hati dalam mengambil kebijakan dalam hal moneter.

2. Indonesia perlu memiliki bargaining position dalam menghadapi ketidakpastian ekonomi global.

3. Jumlah uang beredar dan tingkat bunga berpengaruh negative terhadap pertumbuhan ekonomi. Namun hanya tingkat bunga yang juga berpengaruh signifikan

4. Inflasi berpengaruh positif dan tidak signifikan terhadap pertumbuhan ekonomi.

\section{DAFTAR PUSTAKA}

Bank Indonesia. 2018. Laporan Publikasi [online] .Avaible.at:http://www.bi.go.id [Accesed 19 September 2019]. 2019. Laporan Perekonomian Indonesia. Jakarta

Badan Pusat Statistik. 2019. Statistik Indonesia. Jakarta

Indriyani, S. N. 2016. Analisis Pengaruh Inflasi Dan Suku Bunga Terhadap Pertumbuhan Ekonomi Di Indonesia Tahun 2005 - 2015 . Jurnal Manajemen Bisnis Krisnadwipayana , Vol. 4. No. 2.

Mankiw, N. G. 2013. Pengantar Ekonomi Makro. Jakarta: Penerbit Salemba Empat

Warjiyo, Perry. (2004). Mekanisme Transmisi Kebijakan Moneter di Indonesia. Buku Seri Kebanksentralan Nomor 11. PPSK. Bank Indonesia.

Warjiyo, Perry dan Juhro, Solikin M. 2017. Kebijakan Bank Sentral: Teori dan Praktik. Depok. Rajawali Pers. 